\title{
Die verband tussen skeppingsordinansies en kulturele vormgewing by $\mathrm{A}$. Kuyper
}

\author{
M.F. van der Walt \\ Departement Filosofie \\ Potchefstroomse Universiteit vir $\mathrm{CHO}$ \\ Vaaldriehoekkampus \\ VANDERBIJLPARK
}

\begin{abstract}
The relationship between creational ordinances and cultural formations (as seen by A. Kuyper)

The central statement of this article is that Abraham Kuvper does not make a clear enough distinction between divine normative creational ordinances on the one side, and human cultural structures on the other. Kuyper defines this relationship in a semi-deterministic (organistic) way. The reason for this semi-deterministic approach can be found in Kuyper's neo-Platonic logos-speculation and his RomanticIdealistic use of the organism metaphor. Such a semi-deterministic approach can easily lead to cultural conservatism (for example political conservatism).
\end{abstract}

The proposed answer to Kuyper's problematic approach implies the following:

- Cultural activities should always be seen as free formative action and should not be regarded in a semi-deterministic way.

- Cultural activities should always be seen as being partially the result of the brokenness of man. Consequently, our knowledge of divine ordinances as reflected in these activities will always be provisional.

- Cultural activities should always be seen against the hackground of the divine facilitating structure of the creational ordinances. 
Die verband tussen skeppingsordinansies en kulturele vormgewing by $A$. Kuyper

\section{Inleiding}

Dit is byna onmoontlik om oor die reformatoriese tradisie in die filosofie te skryf sonder om ook deeglik kennis te neem van die grondliggende werk van Abraham Kuyper (1837-1920). Die belangrikheid van Kuyper se bydrae tot die reformatoriese tradisie word algemeen erken (vgl. Dooyeweerd, 1937:63, 65; Dengerink, 1976:88; Schrotenboer, 1988:1; Rastzsch, 1992:1). Langley (1989:8) vat hierdie invloed van Kuyper soos volg saam: "All in all he was one of the greatest leaders of evangelical Christianity since the Reformation". In 'n sekere sin kan Kuyper as die 'vader' van die Neo-Calvinisme ${ }^{1}$ beskou word. Hierdie grondliggende werk geld ook in besonder vir Kuyper se leer van die skeppingsordinansies.

Al het Kuyper dan ook so 'n groot rol in die ontstaan van die reformatoriese filosofie gespeel, en al kan die waarde van sy insette nouliks oorskat word, was hy as persoon 'n baie kontroversiële figuur en is daar ook heelwat kritiek teen sommige van sy standpunte ingebring (Dooyeweerd, 1937:63-65; Velema, 1988:9, 11; Mekkes, 1978:55; Klapwijk, 1980:533-535; 1987:110; Van 't Spijker, 1987:258). Een van die fasette van Kuyper se beskouig wat baie invloed in die Neo-Calvinisme uitgeoefen het, maar terselfdertyd ook baie kritiek ontlok het, is die leer van die skeppingsordinansies (vgl. Wolterstorff, 1983:59; Bartholomew, 1994:67).

Die saak wat besonder problematies in Kuyper se beskouing van die skeppingsordinansies is, is die vraag na die verband tussen die skeppingsordinansies en die kulturele strukture. ${ }^{2}$

Aangesien die leer van die skeppingsordinansies 'n duidelike antwoord gee op die relativisme en historisme van die tyd, is dit van die allergrootste belang dat daar weer indringend besin word oor die korrektheid al dan nie van die grondslae van die leer, soos dit deur Abraham Kuyper ontwikkel is (vgl. Bartholomew, 1994:67).

1 Met Neo-Calvinisme word bedoel die reformatoriese lyn van denke wat ontstaan het deur die 19de-eeuse herlewing van die ortodokse Calvinisme in Nederland onder leiding van persone soos Groen van Prinsterer en Abraham Kuyper (Wolters, 1994:47).

$2 \quad$ Met kulturele strukture word verwys na die kulturele vormgewing van die mens soos dit na vore kom in onder andere die menslike samelewingstrukture soos die staat, huwelik, gesin, kerk, skool en ondernemings. 
M.F. van der Walt

\section{Die leer van die skeppingsordinansies}

\subsection{Geskiedenis}

Die leer van die skeppingsordinansies het 'n lang geskiedenis. ${ }^{3}$ Troost (1994:2 e.v.) gee 'n breedvoerige uiteensetting van die ontwikkelingsgang van hierdie gedagte deur die eeue. Hy volg die spoor van die 'skeppingsorde' terug na Heraclitus (540-480 v.C.) se logosgedagte, die Stösyne se natuurregbeskouing en via Philo tot by die Protestantse teologie waar dit as die leer van die skeppingsordinansies sy beslag gevind het.

Binne die geledere van die reformatoriese denkers het die leer van die skeppingsordinansies sy hoogty gevier in die siening van Kuyper en W. Geesink (Van Egmond \& Van der Kooi, 1994:16-20). Veral as gevolg van die aanwending van die leer van die skeppingsordinansies om Hitler se Nazisme te legitimeer, het hierdie gedagte van die skeppingsordinansies al meer en meer in diskrediet geraak.

Dit wil egter voorkom asof daar opnuut 'n belangstelling in die leer van die skeppingsordinansies besig is om te ontwikkel. Persone soos Wolters (1985, 1992), Van Egmond en Van der Kooi (1994:16-33), Spykman (1994:33-42), Schrotenboer (1994:70-71) en andere begin al toenemend daarvoor pleit dat weer opnuut aandag aan hierdie saak gegee moet word.

\subsection{Wat is skeppingsordinansies?}

Kuyper gaan uit van die gedagte dat die skepping (menslike kulturele strukture ingeslote) 'n duidelike ordelike struktuur deur die geskiedenis heen vertoon. In alles wat bestaan, in die natuur sowel as in die menslike lewe, sien Kuyper orde en reëlmaat. Daar is orde en reëlmaat in die natuur, in die samelewingsverbande soos die kerk, gesin, huwelik, staat, kuns, wetenskap, handel en nywerheid, asook in menslike funksies soos denke, die estetiese, die etiese ensovoorts (Kuyper, 1898:48, 61, 82, 88, 90,$106 ; 1907: 47,49,51,242 ;$ s.j.(c):132, 142, 152-154; 1912:15). Die skepping is vir Kuyper (1898:106) nie soos 'n hoop ongeordende klippe nie, maar soos 'n ordelike monumentale gebou.

Die oorsaak van hierdie orde en reëlmaat in die skepping (onder andere die kulturele strukture) is volgens Kuyper te vind in God se wette of, soos hy

3 Wolters (1994:43-45) wys daarop dat feitlik alle godsdienste een of ander vorm van kosmiese orde erken.

Koers 60(2) 1995:237-258 
Die verhand tussen skeppingsordinansies en kulturele vormgewing by A. Kuyper

dit meestal noem, ordinansies. In God se raad is daar 'n organiese program wat soos ' $n$ beeld van die kosmos is (Kuyper, 1898:107; vgl. Veling, 1984:283). God verwerklik hierdie program, of anders gesê, hy individualiseer hierdie universele beeld van die kosmos deur middel van vaste reëls, ordinansies of wette wat in alle dinge as hul lewenswet ingeskape is (Kuyper, 1932b:491, 493; 1898:107; s.j.(c):151; 1911:246; 1912:28). Dit is hierdie ingeskape skeppingsordinansies wat veroorsaak dat daar orals in die kosmos orde en reëlmaat op te merk is. Die vraag is egter: hoe sien Kuyper die verband tussen die goddelike skeppingsordinansies en die orde in die kulturele strukture?

\subsection{Die aard en funksionering van die skeppingsordinansies}

\subsubsection{Inleiding}

Kuyper se siening van die verband tussen die skeppingsordinansies en die kulturele strukture kom duidelik na vore in sy siening van die aard en funksionering van die skeppingsordinansies. Die aard en funksionering van die skeppingsordinansies word veral bespreek in Kuyper se logosleer en sy organismebeskouing.

\subsubsection{Kuyper se logosleer}

In Kuyper se logosleer ${ }^{4}$ kom die verhouding waarin die skeppingsordinansies en die kulturele strukture tot mekaar staan, baie duidelik na vore (Veling, 1984:285; Dengerink, 1976:96; Klapwijk, 1980:534).

Kuyper plaas die universalia (die wette of skeppingsordinansies), in ooreenstemming met Abaelardus (1079-1142) en Thomas van Aquino (1224/5-1274), ante rem in die goddelike rede of gees, in rebus in die geskape dinge self, en post rem as begrippe in die bewussyn van die mens (vgl. Dengerink, 1977:138; Klapwijk, 1980:534, 535; Van der Walt, 1986:252).

Op tipies Neo-Platoniese wyse plaas Kuyper die universalia, die wette, oftewel die skeppingsordinansies, wat Plato op realistiese wyse buite die kosmos geplaas het, ante rem in die goddelike rede of gees (Wolters, 1993:12). Voor die ontstaan van die kosmos was daar volgens Kuyper $(1932 \mathrm{~b}: 489,490 ; 1898: 107)$ in die goddelike rede of Logos selfstandige denke of ideë waardeur 'n organiese program vir die skepping tot stand

4 Kuyper sluit nou aan by Woltjer se logosbeskouing (Klapwijk, 1980:535, 542). 
M.F. van der Walt

gekom het. Hierdie organiese program bestaan in die Raad van God as beeld van die kosmos (Kuyper, 1898:107). Die organiese program of beeld van die kosmos is eintlik 'n gedagte van God wat konkretisering (beliggaming) soek (Kuyper, 1912:441). Daar moet volgens Kuyper (s.j.(a):67) in die Wêreldskepper 'n denkbeeld wees wat Hy wil verwesenlik. Die universalia lê vir Kuyper as wetmatighede in die Goddelike Logos. Die gedagtes of ideë is dus gereifiseerde ${ }^{5}$ of gesubstansieerde wette (Hart, 1984:63, 64).

Die wette (universalia) wat ante rem in die goddelike Logos bestaan, word nou volgens Kuyper op Aristoteliaans-skolastiese wyse gesien as in rebus, in die dinge self ingeskape. Alles wat bestaan, die kulturele strukture ingeslote, is ' $n$ konkretisering (individualisering) van die goddelike gedagtes (universalia ante rem), want alles het deur die goddelike rede tot stand gekom; alles is ' $n$ uitvloeisel van God se denke en daar bestaan niks wat nie die uitdrukking, die beliggaming of openbaring is van God se denke nie (Kuyper, 1932b:490, 491; 1899:9; 1911:245-247; 1912:416; s.j.(a):67). In die kulturele strukture is gedagtes van God ingeskape (Kuyper, s.j.(b):144; s.j.(c):303, 304, 310-312). Hierdie ingeskape gedagtes is volgens Kuyper 'n selfstandige lewenswet, 'n principium of 'n lex insitia. Die goddelik normatiewe skeppingsordinansies is dus vir Kuyper as gekonkretiseerde universalia in rebus in die kulturele strukture aanwesig (Kuyper, 1932b:490, 491; 1911:246, 247; vgl. Francke, 1978:51, 52).

Die verband wat Kuyper lê tussen skeppingsordinansies en kulturele strukture is baie reglynig: die skeppingsordinansies is in die kulturele strukture ingeskape as lewenswet; die kulturele strukture impliseer die konkretisering van die goddelike gedagtes (ordinansies); die kulturele strukture is die beliggaming van die skeppingsordinansies, en die openbaring van die goddelike denke (skeppingsordinansies ante rem). Alhoewel Kuyper nie 'n identifisering tussen goddelike norm en kulturele strukture bepleit nie, word die band tussen die twee as so sterk gesien dat die onderskeid op kenteoretiese vlak baie moeilik sal wees.

Die verband wat Kuyper lê tussen skeppingsordinansies en kulturele strukture kom nie net duidelik na vore in die aard van die skeppingsordinansies as die individualisering of konkretisering van die goddelike

5 Reifikasie kom van die woord res af, wat ding beteken. Die reifikasie van wette dui op die neiging om wette of norme te verdinglik of as 'n substansie te sien. 
wet, soos hierbo gesien nie. Hierdie verband kom ook duidelik na vore in Kuyper se bespreking van die funksionering van die skeppingsordinansies binne die kulturele strukture. Volgens Kuyper funksioneer die skeppingsordinansies op ' $n$ dwingende manier: dit verskaf detailvoorskrifte en dit bepaal die selfstandige bestaan van elke samelewingstruktuur.

Wat die dwingendheid betref, vergelyk Kuyper (s.j.(c):304) die beheersende rol van die lewenswet (skeppingsordinansie) van elke samelewingsverband met die natuurwetmatigheid waarmee die landbou te doen kry. Hy reken dat die samelewingskringe weens hulle gebondenheid aan hulle lewenswet nie kan doen wat hulle wil nie, net so min as wat die boer kan probeer oes gedurende die verkeerde seisoen. Hierdie vergelyking skep die indruk van 'n byna natuurwetmatige meganiese funksionering van die skeppingsordinansies. Dit is egter ook duidelik dat Kuyper (s.j.(c):131; s.j. (a):51) nie in die slaggat van die Renaissance- en Verligtingsdenke se natuurwetmatige determisme wil trap nie. Die mens is vir hom nie soos 'n masjien wat deur natuurwette beheers word en dus geen vrye keuse het nie. Die mens het wel 'n vrye keuse. Uit bogenoemde beeld kan egter afgelei word dat Kuyper 'n redelike sterk en reglynige verband tussen die skeppingsordinansies en die kulturele strukture sien.

Die sterk verband tussen skeppingordinansies en kulturele strukture kom ook duidelik na vore in Kuyper se idee van die detail-voorskriftelikheid van die skeppingsordinansies. Kuyper $(1898: 61,62)$ vergelyk die skeppingsordinansies met God se natuurwetmatige ordinansies vir die hemelliggame. Die ordinansies wat die lewenswette van die samelewingskringe uitmaak, is nie bloot algemene wette waarvan die toepassing aan die mens oorgelaat word nie. Die ordinansies beheers hierdie samelewingsverbande tot in die kleinste besonderhede, net soos die geval is met die natuurwetmatige beheersing van die kleinste astroïde en grootste sonne (Kuyper, 1898:61, 62). Indien die goddelike skeppingsordinansies die kulturele strukture tot in die fynste besonderhede beheers, is daar nie veel ruimte vir menslike differensiasie of positivering nie. Die gevaar is dan wesentlik dat die gedetailleerde menslike positiveringe gesien sal word as goddelike normering.

Die immanente skeppingsordinansies waarborg ook die selfstandige bestaan van elke samelewingskring (Kuyper, s.j.(c):304). Dit is wel waar dat die lex insitia van die een kring deur 'n ander, byvoorbeeld die staat, oorheers kan word - soos die wetenskap deur die Rooms-Katolieke Kerk oorheers is. Indien dit die geval is, word die betrokke kring bederf (Kuyper, s.j.(c):312, 313). Elke kring het egter volgens Kuyper 'n eie le- 
wenskrag wat dit, soos 'n veer wat te ver teruggedruk is, weer laat regop kom. Ook in die geval van die bepaling van die selfstandigheid van die kulturele strukture (soewereiniteit in eie kring) kom die reglynige verband tussen norm en kulturele struktuur duidelik na vore. Indien alle kulturele strukture sonder meer gesien word as die beliggaming of openbaring van goddelike denke (norme) (Kuyper, 1932b:490, 491; 1899:9), dan beteken dit dat die bestaan van 'n samelewingsverband sonder meer normatief is.

Dit wil dus voorkom asof Kuyper se leer van die skeppingsordinansies, soos dit na vore kom in sy Neo-Platoniese logosspekulasie, 'n semi-deterministiese verband lê tussen die skeppingsordinansies en die kulturele strukture. Hierdie feit blyk duidelik uit die volgende:

* Kuyper se beskrywing van die aard van die skeppingsordinansies as gekonkretiseerde norme (goddelike gedagtes).

* Die funksionering van die skeppingsordinansies as dwingend, as detail-voorskriftelik en as bepalende faktor vir die selfstandigheid van kulturele strukture.

\subsubsection{Kuyper se organismeleer}

Behalwe by die logosleer, kom Kuyper se siening oor die verhouding tussen die skeppingsordinansies en die kulturele strukture ook duidelik na vore in sy gebruik van organisme-metafore. Kuyper se voorliefde vir organisme-metafore is algemeen bekend (vergelyk Klapwijk, 1980:540; Douma, 1984:93; Batteau, 1987:208; Wiskerke, 1978:220; Veling, 1984:277).

Hierdie voorliefde vir die organisme-metafoor is nie 'n bloot onskuldige persoonlike voorkeur nie, en nog minder, soos Batteau (1987:210) beweer, 'n sleutel tot gereformeerde denke. Hierdie organisme-metafoor dui ongetwyfeld op sy aansluiting by die romanties-idealistiese denkrigtings wat gedurende die 19de eeu groot invloed uitgeoefen het (Douma, 1984:133; Keizer, 1980a:27; Trimp, 1975:38; Veling, 1984:278; Strauss, 1993:329) ${ }^{6}$. Kuyper (1908:19 e.v.) spreek dan ook onverbloemd sy bewondering uit vir

$6 \quad$ Keizer (1980a:27; vgl. Dooyeweerd, 1959:9) wys daarop hoe die denke van Schelling via Friederich Julius Stahl (1820-1861) invloed op baie Christene uitgeoefen het, soos byvoorbeeld op Groen van Prinsterer en Abraham Kuyper. Volgens Keizer is veral dié gedagte uit die Romantiek oorgedra, naamlik dat daar in die historiesgeworde lewe (goddelike) normatiwiteit vir menslike handelinge gevind kan word. 
Die verband tussen skeppingsordinansies en kulturele vormgewing by A. Kuyper

die organismegedagte wat persone soos Fichte en Schelling uitgebou het as teenvoeter teen die meganisties-deterministiese benadering van die Verligting. Een van die eienskappe van organismes wat Kuyper (1912:15, 17) op menslike kulturele vormgewing toepas, is die gedagte van noodsaaklikheid (vgl. Veling, 1984:279-286; Trimp, 1975:38).

Wat die ontstaan van die kulturele strukture betref, sien Kuyper (s.j.(c):293) die mens as die hoogste organisme, en daarom spreek dit vanself dat die samelewing (kulturele strukture) van hierdie hoogste organisme ook op organiese manier moet ontstaan. Die menslike geslag is 'n organiese eenheid want uit die eerste mensepaar het die hele menslike geslag voortgekom (Kuyper, 1912:14, 15). Die organiese eenheid van die menslike geslag ontstaan as gevolg van die geboortelike afstamming van die eerste mensepaar. As gevolg van die geboortelike afstamming kan mense nie los van mekaar staan nie, en kom daar vanself (noodwendig?) 'n verband, 'n samelewing tot stand. In Adam is - volgens Kuyper (s.j.(a):51; vergelyk 52; 1912:15-17 ) - ons "vleesch en bloed" reeds teenwoordig. Hiermee bedoel Kuyper dat daar reeds in Adam as eerste mens, die skeppingsordinansies vir die menslike lewe (samelewing ingeslote) ingeskape is. Hierdie verduideliking van Kuyper insake die 'plek' van die skeppingsordinansies verskil van sy uiteensetting van die logosgedagte. In sy logosleer plaas Kuyper die ordinansies in die samelewingsverbande self, terwyl hy dit in hierdie geval in die menslike aard plaas. Die kerngedagte bly egter dieselfde, naamlik detail-ordinansies wat die kulturele strukture bepaal.

Hierdie saak kom baie duidelik na vore in Kuyper (1912:17) se gebruik van die beeld van 'n roos. Die 'saadjie' van 'n roosboom bepaal die ontkiemingsproses, die groei van die boom, die vorming van takke, blare en blomme en self die aantal en kleur van die roos se blare. Kuyper (1912:17) reken dat dit, net soos in die geval van 'n roos, ook in die skepping van die begin af vasgelê is "langs wat lijn en op wat wijs uit den eersten mensch, te midden van die natuur geplaats, onze menschelijke sameleving zou opkomen".

Die skeppingsordinansies vir die samelewing, soos organies ingeskape in die natuur van die mens, bepaal nie net die ontstaan van alle samelewingsverbande nie, maar ook alle moontlike variasies en vorme wat in die loop van die geskiedenis na vore kom (Kuyper, 1912:15-17). In die menslike natuur is daar vaste neigings en trekke geleë wat, hoe uiteenlopend mense ook al mag wees, steeds tot dieselfde resultate (in onder andere die 
M.F. van der Walt

samelewingsverbande) sal lei. Die natuur van die mens (ingeskape wet of skeppingsordinansies) bepaal volgens Kuyper nie net die breë trekke ${ }^{7}$ van die samelewingsverbande nie, maar ook die fyner trekke daarvan. Hierdie gedagte stem ooreen met dit wat Kuyper in sy logosleer oor die rol van die skeppingsordinansies sê (kyk 2.3.2).

Kuyper se gebruik van die organisme-metafoor in die beskrywing van die ontstaan en funksionering van die skeppingsordinansies is egter baie problematies. Natuurwetmatige, en dus deterministiese verskynsels uit die biotiese sfeer word gebruik om menslike kultuurvorming mee te beskryf (vgl. Dooyeweerd, 1959:10; Botha, 1990:90; Douma, 1984:133). Trimp (1975:38) verwys ook na hierdie deterministiese trek wat inherent aan die organisme-metafoor is. Kuyper se siening van die skeppingsordinansies lei daartoe dat hy die verband tussen skeppingsordinansies en kulturele strukture op organisties-deterministiese (semi-deterministiese) wyse interpreteer (vgl. Veling, 1984:285). Strauss (1993:329) bevestig hierdie konklusie deurdat hy van mening is dat daar by Kuyper se siening 'n noodwendig-werkende oerbeginsel op te merk is - 'n beginsel wat ontleen is aan die natuurwetmatige biotiese aard van die organismegedagte.

Dat Kuyper 'n organistiese determinisme ten opsigte van die verband tussen skeppingsordinansies en kulturele strukture huldig, is duidelik. Hierdie organistiese deterministiese benadering mag egter nie gelykgestel word met 'n meganiese determinisme nie. Kuyper (s.j.(c):167-171, 293; vgl. Veling, 1984:278) wil juis in ooreenstemming met die Idealisme en Romantiek en deur middel van die organismebenadering die meganistiese benadering van die Verligting beveg. Die mens is vir Kuyper (s.j.(c):131; s.j.(a):51) nie soos ' $n$ masjien wat oorgelewer is aan die wetmatighede waarin daar geen keusevryheid is nie. Die meganistiese benadering hoort volgens Kuyper (s.j.(a):131; s.j.(c):148-150) by die laer orde van die natuur - die laer orde, wat direk deur God deur middel van sy ordinansies (natuurwette) beheer word sonder enige keusevryheid of moontlikheid van ongehoorsaamheid.

Die mens se keusevryheid ten opsigte van kulturele vormgewing staan vir Kuyper vas. As causa secunda gee God aan die mens vryheid en speelruimte om volgens eie diskresie self besluite te neem in die toepassing van die skeppingsordinansies (Kuyper, s.j.(b):135, 136; s.j.(c):149-151, 168-

7 Kuyper praat in hierdie verband van 'growwer' ontwikkeling. 
Die verband tussen skeppingsordinansies en kulturele vormgewing by A. Kuyper

170). Die mens is vir Kuyper (s.j.(c):167-171) in sy kulturele vormgewing 'n orgaan van God met 'n vryheid van keuse. Die mens is dus nie 'n blote instrument nie. Die vrye vormgewing van die mens as causa secunda word beïnvloed deur verskeie faktore soos byvoorbeeld persoonlikheidsfaktore (aanleg, gawes, persoonlikheid), geleenthede, historiese ontwikkeling, geografiese ligging, ensovoorts (Kuyper, s.j.(c):319, 323, 329, 353, $354 ; 1912: 25-30)$.

Hierdie diskresie en vryheid van kulturele vormgewing wat Kuyper so sterk voorstaan, moet egter geïnterpreteer word binne die raamwerk van die organisme-metafoor. Die menslike diskresie is nie absoluut nie: die mens kan nie sy gesag na goeddunke uitoefen nie, maar kan dit alleen binne die raamwerk van God se ordinansies uitvoer (Kuyper, s.j.(b):135, 136; s.j.(c):168-170). God se ordinansies (in die menslike natuur geleë) bepaal egter ook alle moontlike menslike variasies. Alle kulturele variasies is alreeds in die kiem van die skepping teenwoordig (Kuyper, 1912:17). Die sosiale element van die mens as beeld van God beteken vir Kuyper (1932a:627-629) dat God by die skepping van die mens na sy beeld, 'n eindelose menigte 'kieme' vir hoër menslike ontwikkeling in die natuur van die mens gelê het. Hierdie 'kieme' kan nie tot ontwikkeling kom, behalwe deur die sosiale verband tussen menslike onderling nie. Dié gedagte impliseer dus dat feitlik alle variasies en differensiasies van alle kulturele strukture in geheel op organies-deterministiese wyse bepaal is deur die "eindelose menigte kieme vir hoër menslike ontwikkeling" (Kuyper, 1932a:629).

Kuyper (s.j.(b):136-138) reken dat daar wel onoorkombare teenstrydighede is tussen die idee van God se (organies-deterministiese) beheersing van die samelewing aan die een kant, en die positivering ${ }^{8}$ volgens menslike diskresie aan die ander kant. Waar die causa secunda ook al werk, werk die menslike wil en bly die teenstrydigheid onopgelos, naamlik dat die oorsaak van ons vrye dade in onsself geleë is, maar dat dit as causa secunda deur die causa prima beheers word (Kuyper, s.j.(c):143, 144).

Oor die invloed van die sonde op hierdie organiese ontplooiing van die menslike samelewing is Kuyper redelik vaag. Die (organiese) plan van God is nie deur die sonde versteur nie, maar is wel omgebuig in 'n vasstaande rigting wat op sy beurt ook deur die plan van God bepaal word

$8 \quad$ Kuyper gebruik nie die begrip positivering nie. 
M.F. van der Walt

(Kuyper, 1912:17, 18). Net soos die brandstigter gebonde is aan die wette van die natuur wat vir ontbranding geld, net so is die sonde in sy uitwerking op die omgewing gebonde aan vaste wette wat God vir die menslike lewe en die omgewing gegee het - al verskil is dat die sonde se uitwerking in 'n omgekeerde rigting gaan. Kuyper (1912:19-22) relativeer die uitwerking van die sonde op die samelewing op twee maniere, naamlik deur sy bewering dat sonde 'n nog ryker ontwikkeling van die samelewing moontlik maak en deur sy bewering dat die samelewingsvorme as suiwer formeel en neutraal gesien moet word. Net soos die telegram, spoorweë en plofstof op sigself neutraal is, maar ten goede of ten kwade gebruik kan word, net so kan die samelewing se vorme ook ten goede of ten kwade aangewend word. Hierdie 'neutraliteit' van die histories-ontwikkelde samelewingsvorme (in aard en funksie) bevestig die gevolgtrekking dat Kuyper 'n baie reglynige verband tussen skeppingsordinansies en kulturele strukture sien.

In ooreenstemming met Kuyper se logosleer, wil dit voorkom asof sy organistiese beskouing van die skeppingsordinansies ook neig in die rigting van 'n semi-deterministiese verband tussen die goddelike skeppingsordinansies en die menslike kulturele vormgewing, nieteenstaande sy erkenning van die menslike diskresie en vryheid.

\subsubsection{Gevolgtrekking}

Dit wil voorkom asof Kuyper deur die skolastiese logosleer en die romanties-idealistiese organisme-metafoor 'n onskriftuurlike semi-deterministiese kleur aan die skeppingsordinansies gegee het. Gevolglik kan daar nie voldoende onderskeid gemaak kan word tussen goddelike norme en die menslike positivering van die norme nie. Goddelike wette wat geld vir die kulturele vormgewing word nie voldoende onderskei van menslike historiese differensiasie (kulturele strukture) wat 'n tydgerigte antwoord op die wet is nie. Indien hierdie semi-deterministiese lyn verder ontwikkel sou word, veral as teenvoeter teen relativisme, kan dit maklik tot 'n versteende konserwatisme of status quo-denke lei.

\section{Kennis van die skeppingsordinansies}

Die vraag wat egter nog beantwoord moet word, is wat Kuyper se beskouing oor die kenbaarheid van die immanente skeppingsordinansies is. Trek hy die konsekwensies van die semi-determinisme tot sy volle konsekwensies deur? Indien dit wel die geval is, sou dit impliseer dat God se skep- 
Die verband tussen skeppingsordinansies en kulturele vormgewing by A. Kuyper

pingsordinansies duidelik uit die kulturele strukture kenbaar sou wees. Soos egter dikwels met Kuyper die geval is, werk sy reformatoriese uitgangspunte altyd weer korrigerend in op die skolastiese en idealistiese invloede van sy tyd. In hierdie geval is dit veral sy sondebeskouing wat 'n heilsame invloed op sy denke het.

Die moontlikheid van kennis van God se skeppingsordinansies in onder andere die kulturele strukture, hang volgens Kuyper $(1912: 442$, 443, 416418) saam met die feit dat God aan die mens die vermoë gegee het om sy gedagtes wat in die strukture beliggaam en verborge is, na te dink en sodoende te leer ken. Aangesien die mens as beeld van God in noue verwantskap met Hom staan, is hy daartoe in staat om die gedagtes van God in die kulturele strukture op te spoor en na te dink (Kuyper, 1912:416, $417,443)$. Kuyper (1912:416-417) sê in sy kenmerkende beeldspraak dat God in die wêreld (ook in die kulturele strukture) "als met kleine letterkens zijn Goddelijke gedachte geschreven [heeft], en wij lezen die gedachte Gods van de schepping af'.

Indien daar geen sonde was nie, sou ons met sekerheid die skeppingsordinansies uit die kulturele strukture kon aflei (Kuyper, 1907:50). Die sonde verduister egter die mens se oog en verminder die "gesigskrag van die geestelike oog" (Kuyper, 1912:417, 418, 442-443). Die sonde het veroorsaak dat die allesversteurende en verwoestende bederf daarvan die mens se denke aangetas het en sodoende het die suiwer kennis van God se ordinansies vir die mens verlore gegaan (Kuyper, 1907:50; 1899:10). Kuyper (1912:444) relativeer egter hierdie uitspraak van hom deur te sê dat bogenoemde bederf van die sonde slegs die fynere dele van die kennis betref. Die breë ('growwe') trekke van die skeppingsordinansies is dus wel vir Kuyper kenbaar uit die kulturele strukture self.

Behalwe bogenoemde beperking van die uitwerking van die sonde tot die fynere dele van die kennis van die skeppingsordinansies, erken Kuyer nog drie 'korrektiewe' vir die uitwerking van die sonde - korrektiewe wat naamlik moontlik gemaak word deur die algemene genade, die besondere genade in Christus en die lig van die Skrif.

Vir ongelowige en gelowige geld dit dat die sonde se deurwerking (ook ten opsigte van kennis van die skeppingsordinansies) volgens Kuyper $(1898: 83,84)$ deur die algemene genade gestuit is. As gevolg van die algemene genade het die owerheid byvoorbeeld genoeg lig uit die natuur (ingeskape ordinansies) om God se wil vir die staat te leer ken, al is dit dan 
M.F. van der Walt

op minder volkome wyse. Die kennis wat op hierdie wyse bekom kan word (ook deur die ongelowige), is voldoende vir die uitvoer van die owerheid se taak in beperkte sin.

Die invloed van die sonde word ook deur die besondere genade teengewerk (Kuyper, 1912:444-448). Volgens Kuyper neem die soenverdienste van Christus (besondere genade) by die wedergeboorte die blinddoek van die mens weg waardeur die sfeer van die verborgene vir hom hermeties afgesny was. Die sluier oor God se verborgenhede word ten dele vir hom gelig. Die gelowige ontvang deur die besondere genade 'n hoër mate van vatbaarheid vir God se openbaring in die skepping (waaronder die samelewingsverbande). Selfs die eenvoudigste gelowige kan dus sien wat die ongelowige nie kan sien nie. In Het Calvinisme (1898:63) sê Kuyper dat Christus die stof waarmee die skeppingsorde verberg was, weggevee het sodat die skepping weer in sy oorspronklike helderheid kan skitter.

Die derde relativering van die uitwerking van die sonde is die Heilige Skrif wat God aan die gelowige gee as 'n bril sodat hy daarmee weer God se skrif in die skepping (onder andere kulturele strukture) kan lees - die skrif wat weens die sonde verflou het (Kuyper, 1898:113; 1899:10, 11; vgl. 1907:49). Die probleem is egter dat die ordinansies van God in die Skrif nie soos wetsartikels uitgespel word nie, maar meestal soos gouderts in 'n myn, in verskuilde vorm aangetref word (Kuyper, 1907:51, 242; 1899:10). Die Skrif gee egter wel vir die mens 'n reeks vaste punte waarin daar met taamlike sekerheid rigting aangetoon word. 'n Baie belangrike rol van die Skrif is egter dat dit aan die mens die nodige bevestiging gee van kennis wat uit die natuur (ingeslote samelewingsverbande) self verkry word (Kuyper, s.j.(b):332, 333). Dit beteken dus dat die meeste van die skeppingsordinansies uit die natuur self afgelei kan word, en dat die rol van die Skrif in hierdie verband veral beperk word tot die bevestiging van wat alreeds ontdek is.

Die kennis van die skeppingsordinansies word nog meer ingewikkeld as gelet word op Kuyper se beskrywing van die gereformeerde beginsels in Band aan het woord (1889). Ongelukkig laat die beperke omvang van hierdie artikel nie 'n bespreking van hierdie aspek toe nie.

Uit bogenoemde kan egter afgelei word dat dat Kuyper deur die leer van die sonde nie konsekwent die semi-deterministiese weg van die logosspekulasie en die organistiese benadering opgaan nie. Tog wil dit voorkom asof hy telkens weer die uitwerking van die sonde op die verkryging van 
Die verband tussen skeppingsordinansies en kulturele vormgewing by A. Kuyper

kennis van die skeppingsordinansies relativeer, met die gevolg dat dit wil voorkom asof die goddelike norme tog met redelike sekerheid uit die bestaande kulturele strukture afgelei kan word, veral deur gelowiges.

Op grond van Kuyper se logosleer, sy organistiese benadering en sy siening oor die verkryging van kennis van die skeppingsordinansies, wil dit tog voorkom asof hy nie voldoende onderskeid tref tussen menslike positiveringe en goddelike normering nie.

\section{Konserwatisme}

Indien daar op die basis van Kuyper se siening van die skeppingsordinansies voortgebou word, is die gevaar van kulturele konserwatisme (waaronder politieke konserwatisme) of status quo-denke baie groot. Enkele opmerkings in hierdie verband:

Dit word algemeen erken dat die leer van die skeppingsordinansies in die geskiedenis aangewend is om veral politieke konserwatisme (of status quodenke) te bevorder (Wolterstorff, 1983:58,59; Verkuyl, 1970:33 e.v.; Barth, 1961:20, 126, 127; Langley, 1971:22 en Keizer, 1980b:26, 27).9 Wolterstorff (1983:59; vgl. Van der Hoeven, 1986:6) verwoord hierdie kritiek deur na Dooyeweerd se leer van die skeppingsordinansies (wat op dié van Kuyper gebou is) te verwys as "one more example in that long line of 'creation ordinance' theologies and philosophies that have been used to support conservative positions" (my kursivering - MFvdW). In hierdie verband kan Bartholomew (1994:67) se waarskuwing ernstig opgeneem word: "We need to guard against legalism in the new-Calvinist tradition ...".

Die rede waarom Kuyper se leer van die skeppingsordinansies maklik kan lei tot kulturele konserwatisme, is dat hy nie duidelik genoeg onderskei tussen menslike positivering en goddelike normering nie. Indien die goddelike skeppingsnorme reglynig en duidelik afgelei kan word van die menslike vormgewing in kulturele strukture, is dit byna onvermydelik dat aan sodanige strukture een of ander mate van goddelike normatiwiteit

$9 \quad$ Klapwijk (1987:112) reken dat baie Christene die Franse Revolusie beveg het op grond van die leer van die skeppingsordinansies. Die rede vir dié teëstand is dat gereken is dat dit 'n opstand is teen 'n histories-geworde en dus goddelike instelling. Dooyeweerd (1959:10) Klapwijk (1987:112) en Troost (1994:7 e.v.) wys baie duidelik op die konserwatistiese aanwending van die skeppingsordinansies ter legitimering van Hitler se Nazisme. 
M.F. van der Walt

toegeken sal word (vergelyk Olthuis, s.j.:10). Kulturele strukture wat in die loop van die geskiedenis deur die mens tot stand gebring is, en oënskynlik nie bots met die Woord van God nie, word tot een of ander mate gekanoniseer (Klapwijk, 1980:541; 1987:112; vgl. Douma, 1976:66; Wolterstorff, 1983:62; Langley, 1971:22; Verkuyl, 1970:22, 34; Velema, 1978:48, 49). Samelewingsverbande se vorm en funksies, wat op 'n spesifieke tydstip in die geskiedenis ontstaan het, ontvang dan goddelike normatiwiteit wat ook vir ander tye en omstandighede moet geld.

Indien kulturele strukture na vorm en funksie goddelike normatiwiteit ontvang het, lei dit tot behoudenheid (conservatio, konserwatisme) en dus geslotenheid teen verandering. Indien 'n samelewingsverband 'n redelik eksakte weerspieëling is van God se skeppingsnorme, is enige verandering na vorm en funksie vanself uitgeskakel. Dit wat God se orde weerspieël, kan tog nie verder ontwikkel word of gekorrigeer word nie. Kritiese evaluering van dit wat as normatief gesien word, is vir die konserwatis 'n aantasting van die onaantasbare (vgl. Douma, 1976:66). Konserwatisme laat nie reg geskied aan die dinamiese aard van God se kultuuropdrag en die skeppingsordinansies as sodanig nie (Klapwijk, 1987:114).

Die vraag wat binne die geledere van kulturele konserwatisme onbeantwoord bly, is die volgende: hoe is dit moontlik om die goddelike ordinansies met sekerheid in die kulturele vormgewing te identifiseer indien die volgende in ag geneem word:

* Die groot verskeidenheid positiveringe wat moontlik is weens variasies in kulture, weens historiese differensiasies, weens individuele verskille in aanleg en persoonlikheid (Wolters, 1985:81, 82; 1992:14; Walsh \& Middleton, 1984:15 e.v.; Holmes, 1983:178; Hart, 1984:106, 367; Botha, 1991:163; Roper, 1985:17).

* Die verwringing wat die sonde teweegbring (Griffioen, 1986:104; Roper, 1985:17).

Verskeie persone reken dat die skeppingsordinansies wel uit die kulturele strukture kenbaar is, nieteenstaande die verwringing deur die sonde en die groot verskeidenheid moontlikhede van positivering (Dooyeweerd, 1957:264; Hart, 1984:364-366; Wolters, 1985:25; Botha, 1991:164; Griffioen, 1986:107). Hart (1984:59) verwoord hierdie kenbaarheid van die skeppingsordinansies soos volg: "Order for subjectivity becomes evident in the structure of subjectivity, that is, in patterns of regularity which are themselves subjective." 


\section{Samevattende gedagtes}

\subsection{Vrye vormgewing}

Teenoor Kuyper se semi-deterministiese (konserwatistiese ${ }^{10}$ ) siening van die verband tussen skeppingsordinansies en kulturele strukture, dui die Skrif (Gen. 1) in die rigting van vrye kulturele vormgewing. Die mens is na die beeld van God geskape as heerser of bestuurder en kry ook die opdrag om heerser van die skepping te wees. Hierdie heerskappy van die mens word egter nie semi-deterministies ingeperk tot enkele vaste patrone ten opsigte van die vorm en funksies van samelewingsverbande nie. Die bestuurder van God is geroepe tot vrye vormgewing, tot 'n vrye respons (vgl. Hart, 1984:76). Die ryk potensiaal van die skepping asook die dinamiese ard van die skeppingsordinansies maak hierdie vrye kulturele vormgewing moontlik. Fowler (1987:26) stel dit soos volg: "We are not locked into just one particular way of responding as the one appropriate response ... It is open to us humans to creatively shape the situation by our own contribution".

Alhoewel die goddelike norme absoluut is, is die menslike positivering van daardie norme in kulturele strukture altyd "relatief" ${ }^{11}$ (vgl. Hart, 1984:61; Wolters, 1993:9; Roper, 1985:16, 17; Griffioen, 1986:104-106).

\subsection{Gebrekkige vormgewing en gebrekkige kennis}

Teenoor Kuyper se semi-determinisme moet ook opnuut klem gelê word op die kenteoretiese effek van die sonde. Alhoewel Kuyper (1907:54) die effek van die sonde sterk beklemtoon, word hierdie effek weer telkens gerelativeer. Alhoewel met Spykman (1994:36) saamgestem kan word dat die skeppingsorde wel op een of ander wyse kenbaar is uit die kulturele strukture, moet die effek van die sonde op die kennis nie onderskat word nie. Om hierdie rede maan Wolters (1993:17) ook tot versigtigheid:

10 Vir die Christen behoort die verheffing van histories-geworde kulturele strukture tot normatiewe skeppingsordinansies onaanvaarbaar te wees (Douma, 1976:69, 70; Wiskerke, 1978:221; Francke, 1954:54).

11 Nie 'relatief' in die sin van 'ongenormeerd' nie, maar 'relatief' in die sin van onderhewig aan 'n groot verskeidenheid moontlikhede, afhangende van tyd en situasie en onderworpe aan die invloed van die sonde. 
Assuming that there are given standards for economics or art, what methological safeguards can we devise against epistomological subjectivism in establishing what is normative in these areas?

As gevolg van die effek van sonde op die menslike kenne, moet die voorlopigheid en feilbaarheid daarvan altyd voor oë gehou word. Dit is nie nodig om soos Fowler (1991:85-87) te beweer dat die skeppingsordinansies as gevolg van die sonde glad nie uit die kulturele strukture kenbaar is nie. Botha (1991:164) se benadering, naamlik dat die kulturele strukture 'n toegangspoort bied tot die skeppingsordinansies is korrek, mits Olthuis (s.j.:10, 11) se woorde in gedagte gehou word, naamlik "the provisional and approximate character of human work must be recognized and honored ... Humility and tentativeness are fitting for humans; know-itallness and pride are unbecoming". Bartholomew (1994:67) bevestig hierdie gedagte deur te waarsku teen legalisme in die Neo-Calvinistiese tradisie en deur aan te moedig tot epistemologiese versigtigheid ten opsigte van die leer van die skeppingsordinansies.

\subsection{Genormeerde vormgewing}

Die feit dat die verhouding tussen die skeppingsordinansies en die kulturele strukture nie op konserwatistiese wyse geïnterpreteer word nie, beteken egter nie 'n oorgawe aan ongenormeerde kulturele relativisme nie. Die gevaar is wel groot dat konserwatisme kan oorslaan in sy teendeel, naamlik relativisme.

Die mens se kultuuropdrag dui geensins op 'n absolute heerskappy en totaal vrye vormgewing nie. Die mens is slegs God se bestuurder en daarom moet kulturele vormgewing ook genormeerde vrye vormgewing wees. Daar moet vasgehou word aan die bestaan van God se onveranderlike norme wat vir alle mense en alle tye en alle situasies geld (vgl. Hart, 1984:59; Wolters, 1993:9; Roper, 1985:16, 17; Velema, 1978:48-50; Douma, 1976:66). Kultuur is eers werklik skeppingsontplooiing indien dit geskied volgens God se norme vir die ontplooiing. Menslike vormgewing behoort slegs positivering te wees van die goddelike norme en sodoende aktualisering van die geskape potensiaal (vgl. Fowler, 1987:32, 33). Hierdie norme (skeppingsordinansies) mag egter nie semi-deterministies gesien word as streng beherend nie, maar eerder, in aansluiting by Fowler (1987:23, 33) as 'n fasiliterende struktuur wat vrye menslike vormgewing moontlik maak en rig. 
Die verband tussen skeppingsordinansies en kulturele vormgewing by A. Kuyper

\section{Literatuurlys}

BARTH, K. 1961. Church Dogmatics. Vol. III. Edinburgh : Clark.

BARTHOLOMEW, C.G. 1994. Response to Al Wolters's Paper. (In Van der Walt, B.J., ed. God's Order for Creation. Potchefstroom : PU for CHE. p. 61-70.)

BATTEAU, J.M. 1987. De theologie van Abraham Kuyper: een beoordeling. Radix, 13(4):188-218.

BOTHA, M.E. 1990. Metateoretiese perspektiewe op die sosiale wetenskappe. Potchefstroom : PU vir CHO.

BOTHA, M.E. 1991. Elementêre inleiding tot die wetenskapsleer. Potchefstroom : PU vir CHO.

DENGERINK, J.D. 1976. Kuyper's wetenschapsleer. Radix, 2(2):87-102, Jan.

DENGERINK, J.D. 1977. Samehang der wetenschappen. Radix, 3(1):135148 , Jan.

DOOYEWEERD, H. 1937. Wat de wijsbegeerte der wetsidee aan dr. Kuyper te danken heeft. De Reformatie: 63-65, Okt.

DOOYEWEERD, H. 1957. A New Critique of Theoretical Thought. Vol. III. Amsterdam : Paris.

DOOYEWEERD, H. 1959. The Criteria of Progressive and Reactionary Tendencies in History. Address commemorating the 150th anniversary of the Koninklijke Nederlandse Academie van Wetenschappen. A'dau : Noord-Hollandse Uitgevers.

DOUMA, J. 1976. Kritische antekeningen bij de Wijsbegeerte der Wetsidee. Groningen : De Vuurbaak.

DOUMA, J. 1984. Politieke verantwoordelijkheid. Kampen : Van den Berg.

FOWLER, S. 1987. The Christian's Social Calling. Potchefstroom : PU for CHE.

FOWLER, S. 1991. A Christian Voice among Students and Scholars. Potchefstroom : PU for CHE.

FRANCKE, J. 1954. De kerk en het sociale vraagtuk. Enkele beschouwingen. Rotterdam : Firma Groenendijk.

FRANCKE, J. 1978. Thomas van Aquino. Radix, 4(1):51-54, Jan.

GRIFFIOEN, S. 1986. De betekenis van Dooyeweerd's ontwikkelingsidee. Philosophia Reformata, 51:83-109.

HART, H. 1984. Understanding Our World. An Integral Antology. Lanham : University Press of America.

HOLMES, A.F. 1983. Contours of a World View. Grand Rapids : Eerdmans.

KEIZER, A. 1980a. Wat is christelijke wetenschap? Bijbel en Wetenschap, 37:33-37, Okt.

KEIZER, A. 1980b. Wat is christelijke wetenschap? Bijbel en Wetenschap, 38:11, 26-30, Des. 
M.F. van der Walt

KLAPWIJK, J. 1980. Honderd jaar filosofie aan de Vrije Universiteit. (In Van Os, M. \& Wieringa, W.J., reds. Wetenschap en rekenschap 1880-1980. Een eeuw wetenschapsbeoefening en wetenschapsbeschouwing aan de Vrije Universiteit. Kampen : Kok. p. 529-593.)

KLAPWIJK, J. 1987. Reformational Philosophy on the Boundary between the Past and the Future. Philosophia Reformata, 52(2):101-123.

KUYPER, A. 1898. Het Calvinisme. Zes Stone-lezingen. Amsterdam : Hoveker \& Wormser.

KUYPER, A. 1899. Band aan het woord. Antwoord op de vraag: Hoe is eene universiteit aan het woord van God te binden? Amsterdam : Hoveker \& Wormser.

KUYPER, A. 1907. Ons program. Hilversum : Hoveker \& Wormser.

KUYPER, A. 1908. Encyclopaedie der Heilige Godgeleerdheid. Eerste deel. Kampen : Kok.

KUYPER, A. 1911. Pro Rege of het koningschap van Christus. Eerste deel. Kampen : Kok.

KUYPER, A. 1912. Pro Rege of het koningschap van Christus. Derde deel. Kampen : Kok.

KUYPER, A. 1932a De gemeene gratie. Tweede deel. Kampen : Kok.

KUYPER, A. 1932b De gemeene gratie. Derde deel. Kampen : Kok.

KUYPER, A. s.j.(a). Dictaten dogmatiek. Vol. II. Kampen : Kok.

KUYPER, A. s.j.(b). Dictaten dogmatiek. Vol. III. Kampen : Kok.

KUYPER, A. s.j.(c). Dictaten dogmatiek. Vol. V. Kampen : Kok.

LANGLEY, M.R. 1971. Groen van Prinsterer. Vanguard. Christian Vision of the Seventies: 7-9, April 22.

LANGLEY, N.R. 1989. Guilluame Groen van Prinsterer (1801-1876). Vader van die antirevolusionêre reformatoriese politiek. Potchefstroom : PU vir CHO.

MEKKES, J.P.A. 1978. De grenzen van het denken - een gesprek. Radix, 4(1):55-65, Jan.

OLTHUIS, J.H. s.j. Visions of Life and Ways of Life: The Nature of Religion. (Ongepubliseer.)

RASTZSCH, D. 1992. Abraham Kuyper's Philosophy of Science. (Paper delivered on 11-15th August 1992 at the Pascal Centre International Conference of Science and Belief.) Ontario. $38 \mathrm{p}$. (Ongepubliseer.)

ROPER, D.L. 1985. A Christian Philosophy of Culture. Potchefstroom : PU for CHE.

SCHROTENBOER, P.G. 1988. Abraham Kuyper: His International Influence. Theological Forum, 16(2):1-2, Jun.

SCHROTENBOER, P.G. 1994. Postscript. (In Van der Walt, B.J., ed. God's Order for Creation. Potchefstroom : PU for CHE. p. 70-71.) 
Die verband tussen skeppingsordinansies en kulturele vormgewing by A. Kuyper

SPYKMAN, G.J. 1994. Thoughts on "Creation Order". (In Van der Walt, B.J., ed. God's Order for Creation. Potchefstroom : PU for CHE. p. 3342.)

STRAUSS, P.J. 1993. Abraham Kuyper, ras en volk in Suid-Afrika. In die Skriflig, 27(3):323-336.

TRIMP, C. 1975. De ampten bij A. Kuyper. Een schets. Radix, 1(1):37-44, Jan.

TROOST, A. 1994. The Idea of Creation Order in Western Thought. (In Van der Walt, B.J., ed. God's Order for Creation. Potchefstroom : PU for CHE. p. 2-16.)

VAN 'T SPIJKER, W. 1987. Kuyper en de Christelijke Gereformeerde Kerk van 1892. Radix, 13(4):258-264, Jan.

VAN DER HOEVEN, J. 1986. Na 50 jaar: Philosophia Reformata philosophia reformanda. Philosophia Reformata, 51(1\&2):5-28.

VAN DER WALT, B.J. 1986. Van Atene na Geneve. Kort oorsig oor die geskiedenis van die Wysbegeerte vanaf die Grieke tot die Reformasie. Potchefstroom : PU vir CHO.

VAN EGMOND, A. \& VAN DER KOOI, C. 1994. The Appeal to Creation Ordinances: a Changing Tide. (In Van der Walt, B.J., ed. God's Order for Creation. Potchefstroom : PU for CHE. p. 16-33.)

VELEMA, W.H. 1978. Solidariteit en antithese. Een theologische peiling. Kampen : Kok.

VELEMA, W.H. 1988. Abraham Kuyper - Born 150 Years Ago: A Study in Strengths and Pitfalls. Theological Forum, 16(2):9-14, Jun.

VELING, K. 1984. Kuypers visie op de wetenschap als organisme. Kanttekeningen bij een metafoor. ( $I n$ Bezieid verband. Opstellen aangeboden aan prof. J. Kamphuis bij gelegenheid van zijn vijfentwintig-jarige ambsjubileum als hoogleraar an de Theologische Hogeschool van de Gereformeerde Kerken in Nederland te Kampen op 9 April 1984. Kampen : Uitgeverij van den Berg.)

VERKUYL, J. 1970. Hoe hebben kerk en theologie de facto gereageerd op de uitdagingen van de tijd. (In Verkuyl, J. \& Nordholt, H.G.S., reds. Verantwoorde revolutie. Over middelen en doeleinden in de strijd om transformatie van samelevingskringen. Kampen : Kok. p. 23-42.)

WALSH, B.J. \& MIDDLETON, J.R. 1984. The Transforming Vision: Shaping a Christian Worldview. Illinois : Intervarsity Press.

WISKERKE, J.R. 1978. De strijd om de sleutel der kennis. Een bundel opstellen over theologie en filosofie. Groningen : De Vuurbaak.

WOLTERS, A.M. 1985. Creation Regained. Biblical Basics for a Reformational Worldview. Grand Rapids : Eerdmans.

WOLTERS, A.M. 1993. Creation Order: An Historical Look at Our Heritage. Voordrag gelewer by die Stokerlesings 1993, PU vir CHO. 
M.F. van der Walt

WOLTERS, A.M. 1994. Creation Order: A Historical Look at Our Heritage. (In Van der Walt, B.J. ed. God's Order for Creation. Potchefstroom : IRS. p. 42-61.)

WOLTERSTORFF, N. 1983. Until Justice and Peace Embrace. The Kuyper Lectures for 1981 delivered at the Free University of Amsterdam. Kampen : Kok. 
